\title{
FEMALE GAZE PADA FILM “LADY BIRD”
}

\author{
Fathin Hanifah Langga \\ Email: fathinlangga@gmail.com
}

\begin{abstract}
The box office movie Lady Bird received many awards and positive reviews from critics. An interesting thing that can be discussed from the Lady Bird movie is about female gaze. Analyze by comparing Laura Mulvey's theory of female gaze and male gaze through the phenomena found in the Lady Bird which tells the life of a teenage girl in general. The image of women in the Lady Bird does not appear as an object but rather a subject, the female actor in the Lady Bird appears strong, ambitious and optimistic. Lady Bird proved that Mulvey's theory of the patriarchal world is not permanent and not mandatory.
\end{abstract}

Key Words:female gaze, male gaze, voyeurisme, patriarchy, film

\begin{abstract}
Abstrak: Film box office Ladybird mendapatkan banyak penghargaan dan review positif dari para kritikus. Hal menarik yang dapat dibahas dari film Lady Bird adalahmengenai female gaze. Menganalisis Dengan Membandingkan Teori Laura Mulvey Mengenai Female gaze dan male gaze melalui fenomena yang terdapat pada film Lady Bird yang menceritakan kehidupan seorang remaja perempuan pada umumnya. Image perempuan dalam film Lady Bird tidak tampak sebagai sebuah objekmelainkan sebuah subjek, gayapemeranperempaun dalam film Lady Bird tampilkuat, ambisius dan optimis. Lady Bird membuktikan bahwa teori Mulvey tentang dunia patriarkal tidak permanen dan tidak wajib.
\end{abstract}

Kata kunci:female gaze, male gaze, voyeurism, patriarchy, movie

Film merupakan fenomena sosial, psikologi, dan estetika kompleks yang merupakan dokumen dari cerita dan gambar yang diiringi kata-kata dan musik, sehingga film merupakan produksi yang multi dimensional dan kompleks. Kehadiran film di tengah kehidupan manusia saat ini semakin penting dan setara dengan media lain. Keberadaannya dapat dikatakan hampir tidak ada kehidupan sehari-hari manusia berbudaya maju yang tidak tersentuh dengan media ini.

Salah satu film yang digemari masyarakat adalah jenis film box office. Box office atau kantor tiket adalah tempat di mana tiket dijual untuk umum untuk masuk ke sebuah acara. Penonton dapat melakukan transaksi di meja, melalui sebuah lubang di dinding atau jendela, atau di gawang. Dalam hal ini, film box office juga dikenal sebagai film yang tayang di bioskop. Seperti contohnya film box office yang mendapatkan review positif dari para kritikus adalah film berjudul Lady Bird. Film ini telah mendapatkan banyak penghargaan, diantaranya sebagai film komedi terbaik dalam Golden Globe 2018, selain itu Lady Bird juga terpilih menjadi salah satu film yang masuk nominasi piala Oscar di ajang penghargaan perfilman paling bergengsi yaitu Academy Awards ke-90. Film Lady Bird telah berhasil masuk dalam 5 nominasi sekaligus dalam ajang penghargaan tersebut.

Lady Bird merupakan film drama independen komedi Amerika Serikat tahun 2017 yang disutradarai oleh Greta Gerwig dan diproduseri oleh Scott Rudin, Eli Bush dan Evelyn O'Neil. Naskah filmnya ditulis oleh Greta Gerwig. Film Lady Bird perdana ditayangkan di Festival Film Telluride pada tanggal 1 September 2017 dan dirilis di Amerika Serikat pada tanggal 3 November 2017 secara terbatas dan 24 November 2017 secara luas, di Indonesia sendiri film ini rilis pada tanggal 28 Februari 2018. Film ini dibintangi oleh Saoirse Ronan, Laurie Metcalf, Tracy Letts, Lucas Hedges, Timothée Chalamet, Beanie Feldstein, Stephen McKinley Henderson dan Lois Smith.

Lady Bird menceritakan kehidupan seorang remaja perempuan pada umumnya. Meski menampilkan cerita romansa tetapi yang menjadi fokus cerita bukanlah tentang pacaran, melainkan hubungan ibu dengan anak perempuannya. Berbeda dengan film kebanyakan, konflik yang terjadi disini adalah tentang kasih sayang dengan cara 
penyampaian berbeda.

Lady Bird menggambarkan masa remaja Christine yang pemberontak namun sebenarnya ia merupakan anak remaja yang rapuh dan butuh perhatian. Sekilas, hubungan ibu dan anak yang ditampilkan dalam Lady Bird merupakan peristiwa kebencian, padahal sebenarnya keduanya hanya adu ego. Christine anak remaja impulsif yang memiliki ibu overprotektif. Sesungguhnya mereka saling mencintai, namun juga kerap kesal satu sama lain. Terlepas dari alur ceritanya, terdapat hal menarik lainnya yang tentunya akan menjadi pembahasan utama yaitumengenaifemale gaze dalam film Lady Bird. Female gaze merupakan sebuah istilah yang mulai trend beberapa dekade belakangan ini, sebagai sebuah reaksi untuk memperkuat kritik Laura Mulvey terhadap kebudayaan dominan patriarki pada 1975. Mulvey menggunakan istilah male gaze untuk membongkar moda produksi kebudayaan dan media pada masa itu.

\section{PENDEKATAN TEORI}

Banyak mitos yang menjadikan kedudukan perempuan berada lebih rendah dibanding laki-laki. Perempuan biasa dipandang dari segi seks, bukan kemampuan, kesempatan, dan aspek-aspek manusiawi secara universal, yaitu sebagai manusia yang berakal, bernalar, dan berperasaan. Lekuk tubuh mampu membangkitkan sisi sensual perempuan (King dalam Kosakoy, 2016: 4). Penampilan fisik pada perempuan menjadi hal penting untuk dinilai seseorang. Terlebih bagi perempuan bahwa perempuan yang ideal adalah tampil cantik dan langsing (Wood dalam Kosakoy, 2016: 4). Perempuan juga dianggap tidak memiliki kekuatan fisik, lemah, dan cenderung emosional, sehingga hanya berhak mengerjakan pekerjaan yang halus, seperti pekerjaan rumah, mengasuh anak, dan lain-lain.

Pelabelan stereotype feminin pada perempuan mengidentikkan dengan pekerjaan di rumah. Peluang bekerja di luar terbatas sehingga perempuan tidak dapat mengaktualisasi diri. Memang perempuan berkembang dan sudah mulai memasuki ranah publik dalam artian mulai banyak perempuan bekerja, namun perkembangan perempuan tidaklah mengubah peranannya yang lama yaitu peranan dalam lingkup rumah tangga (peran reproduktif). Dalam tingkah lakunya, perempuan distereotipkan asyik dengan lakilaki dan anak-anak, juga terlibat dalam hubungan-hubungan antar manusia (Holtzman dalam Kosakoy, 2016: 4)

Posisi perempuan dalam sebuah film memang bukan wacana yang baru lagi untuk diperbincangkan. Tuchman (1979:51) mengatakan bahwa perempuan dalam pandangan laki-laki adalah sebagai objek seksual. Perempuan dihadirkan dalam media, namun tidak lepas hanya sebagai objek seksual bagi laki-laki. Lauretis (1987:13) menjelaskan bagaimana perempuan menjadi objek hasrat bagi penonton (voyeurist gaze).

Laura Mulvey sebagai pencetus teori male gaze, mengawali teorinya dengan pernyataan bahwa film memberikan beberapa kepuasan, salah satunya adalah kepuasan dalam pandangan atau disebut dengan scopophilia. Kepuasan dalam memandang dibagi menjadi dua, yaitu laki-laki sebagai pihak yang aktif dan perempuan sebagai pihak yang pasif (Mulvey, 1989: 19). Perempuan yang pasif menjadi objek seksual dari pandangan laki-laki heteroseksual yang melihatnya dan laki-laki tersebut mendapatkan kenikmatan dari pandangan tersebut.

Selain itu, Mulvey juga menggunakan pendekatan psikoanalisis Lacanian dalam menganalisa bagaimana pandangan sinematik terorganisasi seperti layaknya bahasa berdasarkan kode-kode dan ketentuan patriarki, dan maskulinitas 'dikuatkan ' melalui tindakan melihat, sedangkan femininitas dilemahkan dengan menjadi objek pasif yang dilihat. Mulvey berpendapat bahwa perbedaan seksual mengatur bagaimana kita menonton sebuah film dimana pemeran laki-laki menghidupkan fantasi-fantasi dan obsesiobsesinya.

Film Lady Bird hadir dengan cerita yang berani menentang budaya penindasan wanita yang telah lama berdiri, menolak partisipasi dalam kekuasaan laki-laki dan menyatakan bahwa perspektif berpusat pada wanita dimungkinkan dalam film. Lady Bird merupakan cerita yang menghadirkan perempuan sebagai pihak yang aktif, menunjukkan bahwa tatapan laki-laki dianggap tidak penting dan tidak terlalu terekspos. 


\section{PEMBAHASAN}

Pada film Lady Bird tokoh Christine sebagai remaja menciptakan dunia sinematik yang berpusat pada suara, ambisi, dan keinginannya. Christine mewarnai rambutnya dengan warna pink cerah dan memberi nama dirinya sebagai "Lady Bird".

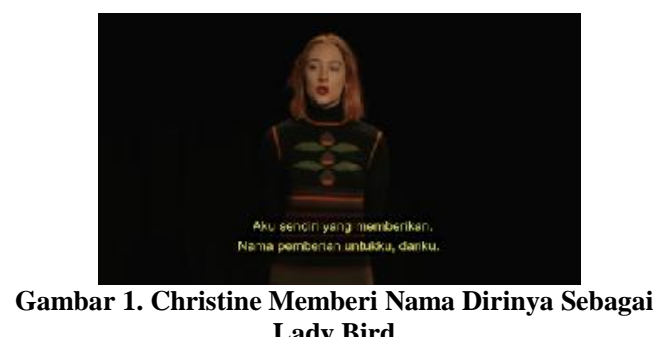

Saat sedang berbincang bersama Julie, Christine sangat optimis dan percaya diri bahwa dirinya mampu mendapat beasiswa untuk kuliah ke New York.

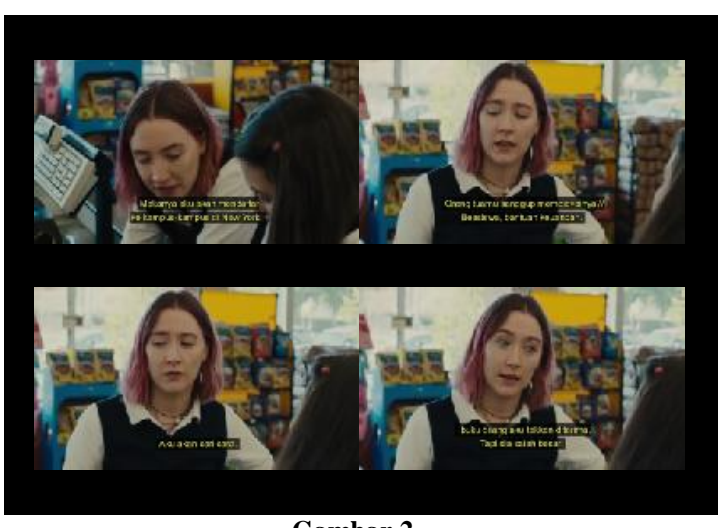

Gambar 2.

ChistinebersamaJullieberdialogtentangbeasiswakuliahke New York

Christine dengan berani berbicara pada Kepala Sekolahnya tentang keinginan untuk mengikuti Olimpiade matematika meski ia tidak memiliki kemampuan yang baik dalam mata pelajaran matematika.

Christine juga berani menjatuhkan dirinya keluar dari mobil yang sedang melaju ketika ia dan ibunya berdebat tentang pergi kuliah ke perguruan tinggi di Pesisir Timur.

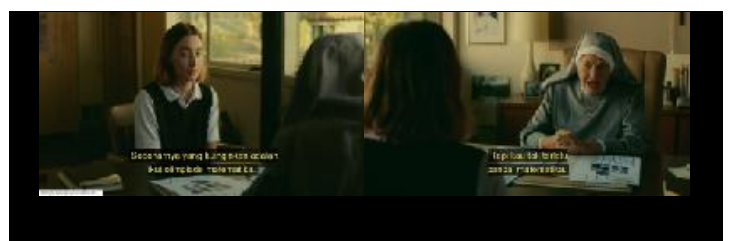

Gambar 3. Christine bersama Kepala Sekolah

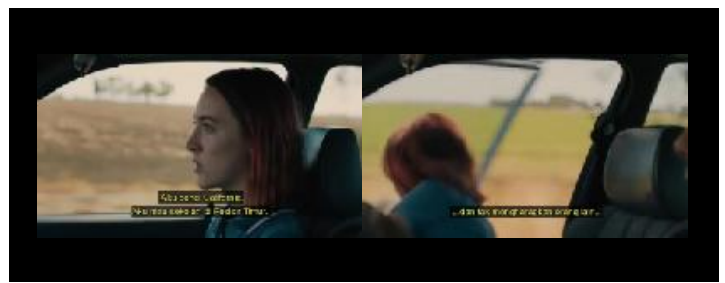

Gambar 4. Christine Menjatuhkan Dirinya Keluar dari mobil yang sedang melaju

Menolak kepasifan, film Lady Bird seolah menepis argumen Mulvey bahwa perempuan pasif. Kamera tidak pernah lambat untuk membuat kehadiran visual Christine menjadi pusat perhatian. Sebaliknya, fokusnya adalah konsisten pada kehadiran aktif Christine dengan dialognya yang tajam dan impiannya yang ambisius. Tidak ada gambaran atau bidikan close-up dari tubuhnya yang membuatnya tunduk pada tatapan seksual atau yang menekankan dia harus tampak menggugah hasrat lelaki. Christine liar dan cantik, tapi dia tidak pernah digambarkan sebagai tontonan erotis.

Bahkan, bertentangan dengan male gaze, film ini menetapkan Christine sebagai perempuan aktif. Selain itu juga, peran ibu kandung Christine tampak sebagai perempuan aktif dibanding suaminya, sang ibu diceritakan sebagai perawat yang merupakan tulang punggung keluarga namun ia pun harus mengurus keluarga sedangkan suaminya seorang pengangguran.

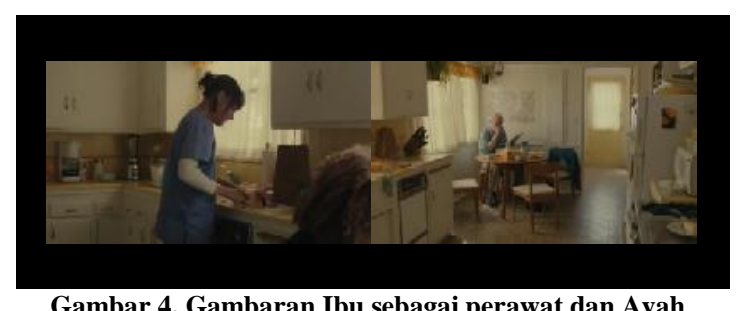

Gambar 4. Gambaran Ibu sebagai perawat dan Ayah sebagai pengangguran

Banyak film dengan tokoh laki-laki yang memimpin, dari waktu ke waktu telah membentuk khalayak menjadi percaya bahwa pandangan patriarki lelaki-sentris adalah suatu hal yang alami. Dengan membuat wanita 
protagonis dan pria sebagai objek tatapan perempuan, pandangan patriarki dunia dalam film dapat diperdebatkan. Protagonisme Christine memberi kekuatan pada tatapan perempuannya sepanjang film.

Dalam hubungannya dengan dua senior laki-lakinya, kamera secara konsisten menggambarkan anak laki-laki sebagai subjek tatapannya. Dalam adegan cinta pandangan pertamanya, Christine menatap Danny yang bernyanyi di atas panggung untuk audisi teater di sekolah. Kamera tetap hidup, fokus dan terang pada tokoh sedangkan di latar belakang yang gelap seolah menggambarkan terisolasi, glamor, dan sengaja untuk memamerkan si tokoh yang sedang dibidik. Kamera kemudian beralih kembali ke wajah bersinar Christine di antara penonton, membenarkan bahwa Danny yang sedang dipamerkan telah menjadi orang yang diinginkannya.

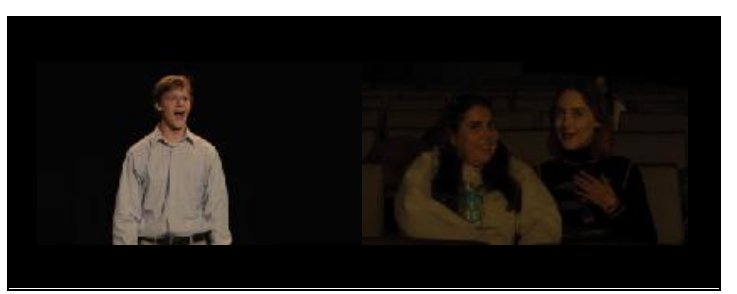

Gambar 5. Christine menatap Danny yang bernyanyi di atas panggung

Christine menetapkan dirinya sebagai sosok yang dapat mengendalikan diri dalam hubungannya dengan Danny. Ia secara aktif tampak berani untuk menghampiri Danny di supermarket dan memperkenalkan dirinya.

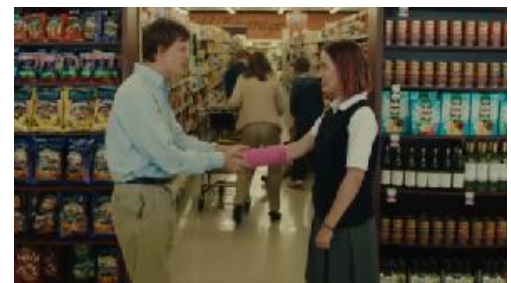

Gambar 6. Christine menghampiri Danny di supermarket

Saat acara prom night, Christine dengan berani menyapa dan mengajak Danny untuk berdansa, terlihat sangat spontan, tak ada keraguan sama sekali dalam tindakan yang ia lakukan.

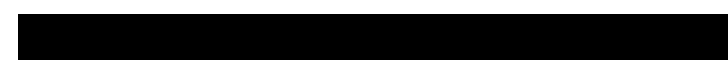

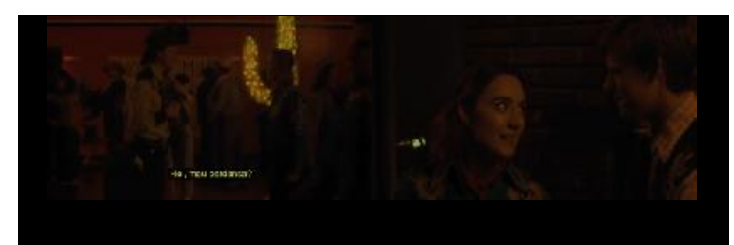

Gambar 7. Christine mengajak Danny berdansa

Dalam adegan selanjutnya diperlihatkan Christine bertanya pada Danny untuk memegang payudaranya, namun Danny menolak dengan alasan bahwa dirinya menghormati Christine sebagai perempuan. Meskipun pada akhirnya Danny diketahui sebagai homo. Mungkin alasannya menghormati Christine adalah sebuah manipulasi agar ia tak ketahuan sebagai homo.

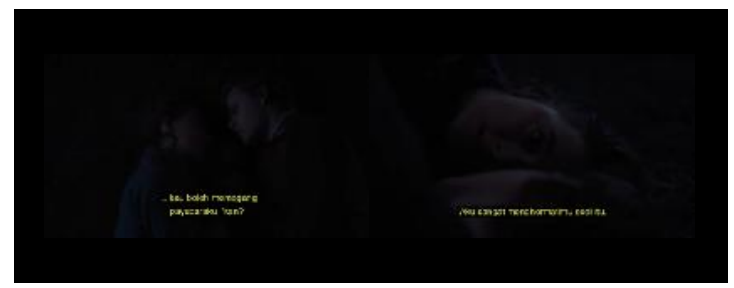

Gambar 8. Christine bertanya pada Danny untuk memegang payudaranya

Dalam adegan lain kemudian pada film ini, Christine mengidentifikasi anak lakilaki lain yang menarik. Christine menatap lelaki yang sedang bermain gitar pada sebuah band di acara pesta. Kamera perlahan-lahan memperbesar anak laki-laki yang sedang menarik perhatian Christine.

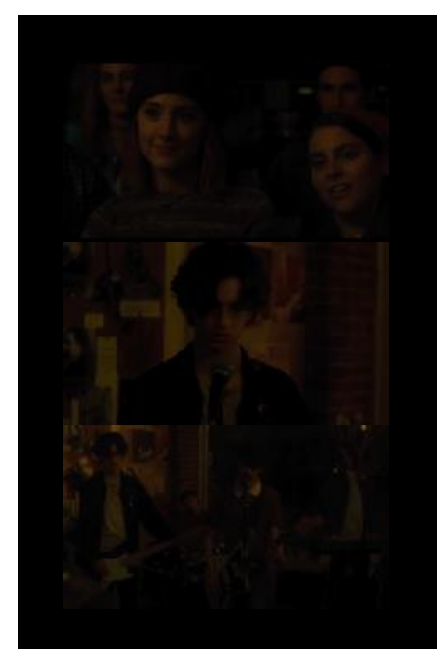

Gambar 9. Christine menatap lelaki yang sedang bermain gitar di pesta

Penonton diminta untuk mengidentifikasi bahwa Christine sedang terkagum-kagum pada lelaki itu, saat itu pula 
ia menjadikannya sebagai orang yang penting. Tatapan Christine pada anak lelaki sebagai objek merupakan konsistensi film Lady Bird. Protagonisnya memungkinkannya mengubah apa yang disebut hasrat jantan ke dalam hasrat wanita, memungkinkannya untuk memiliki kekuatan pada sebuah tatapan.

Namun, film tidak bisa begitu saja menghilangkan tatapan lelaki dengan menjadikan perempuan sebagai pemeran utama. Sebagai penulis dan sutradara perempuan, Gerwig memproyeksikan visi non-patriarki dunia ke dalam layar. Visinya menentang objektifikasi wanita dan memungkinkan mereka untuk melampaui penampilan mereka. Melalui kontrol pada setiap langkah proses produksi, dia memastikan bahwa female gaze alami diadopsi ke dalam film. Hal ini bukan untuk mengatakan bahwa semua wanita menganggap female gaze. Sebaliknya, wanita cenderung kurang memiliki pandangan kuat, melainkan sebagai bahan pasif, mentah, dan erotis. Dengan demikian, film yang disutradarai oleh perempuan membuat kemungkinan pembangkangan terhadap male gaze.

Selain berbagi pandangan, perasaan yang dibagikan sangat penting untuk memungkinkan pemirsa untuk berbagi berdasarkan perspektif wanita. Seringkali lakilaki tidak dapat memahami antara posisi tokoh perempuan, seperti Christine dan ibunya. Laki-laki dalam kehidupan ini tidak memahami kehadiran perempuan yang kuat, seringkali tidak dapat memahami secara akurat bagaimana cara perempuan berinteraksi, dan melepaskan apa yang mereka rasakan. Film Lady Bird mencapai perasaan dengan mengadopsi gaya visual bersahaja dimana sebagian besar bidikan kamera fokus dan tidak bergerak.

Ketika adegan kamera diam menyorot dialog dan memungkinkan penonton untuk menyerap kata-kata dan emosi dari karakter pada tokoh di film ini. Seperti dalam bidikan pembuka film, saat Christine dan ibunya duduk berdampingan di tempat tidur dengan punggung mereka ke kamera.

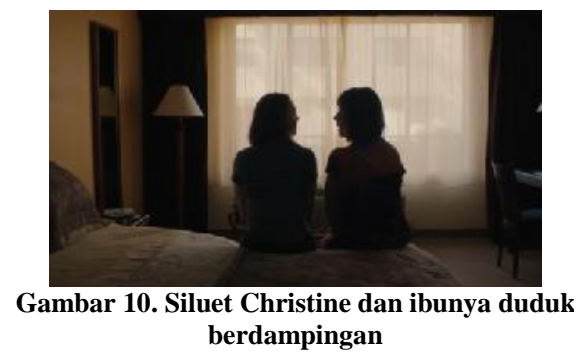

Adegan ini disita oleh dua karakter yang sedang mengambil momen itu. Kamera tidak bergerak untuk melihat ibu dan anak perempuan, tetapi sebaliknya membiarkan siluet mereka saja yang terlihat. Film Lady Bird mengundang penonton untuk merasakannya daripada melihatnya.

\section{KESIMPULAN}

Membuat para penonton laki-laki untuk menatap dan fokus pada perasaan tentu saja secara visual tampak sulit. Lady Bird menyatakan bahwa film yang memfokuskan laki-laki untuk menatap perempuan bukanlah hal yang tidak mungkin. Gaya film Hollywood telah lama mengambil bahasa patriarki, tetapi norma-norma ini dapat didefinisikan ulang. Seperti yang ditunjukkan Lady Bird, film dapat menindas pandangan laki-laki dengan menampilkan protagonis perempuan yang tidak bermain pada keinginan laki-laki yang voyeuristik.

Sutradara laki-laki memiliki kecenderungan yang lebih besar untuk memproyeksikan visi patriarkalnya ke layar, pandangan perempuan paling baik dicapai seringkali oleh seorang sutradara perempuan yang memiliki keinginan untuk dunia nonpatriarkal. Sutradara dapat fokus pada konten dan dialog wanita atas penampilan mereka untuk membangkitkan perasaan bersama dengan penonton.

Image perempuan dalam film Lady Bird tidak tampak sebagai sebuah objek melainkan sebuah subjek, gaya pemeran perempuan dalam film Lady Bird tampil kuat, ambisius dan optimis.

Lady Bird membuktikan bahwa teori Mulvey tentang dunia patriarki tidak permanen dan tidak wajib. Dominasi male gaze memang merupakan hasil dari hasrat voyeuristik laki-laki, tetapi pada umumnya, hal ini merupakan cerminan dari perbedaan gender dalam industri film yang telah 
menghalangi perempuan untuk menceritakan kisah-kisah mereka. Industri film telah dan masih didominasi oleh laki-laki yang ingin memproyeksikan dunia patriarki mereka, tetapi Greta Gerwig meyakinkan kita bahwa ada potensi untuk perubahan.

\section{DAFTAR PUSTAKA}

Kosakoy, Joane Priskila. (2016): Representasi Perempuan Dalam Film "Star Wars VII: The F orce A wakens", diunduh dari https://media.neliti.com/media/publicati ons/82771-ID-representasi-perempuandalam-film-star-w.pdfpada tanggal 02 Mei 2018, jam 20.10.

Lauretis, Teresa de. (1987): Technologies of Gender, Essays on Theory, Film and Fiction. Bloomington dan Indianapolis: Indiana University Press, 13.

Mulvey, Laura. (1989): Visual and Other Pleasure. New York: Palgrave, 19.

Tuchman, Gaye. (1979): Women's Depiction by the Mass Media. Sign. 4: 528-542, 51 . 